\title{
PRELIMINARY ESTIMATE OF INCIDENTAL MORTALITY OF COMMERSON'S DOLPHINS (CEPHALORHYNCHUS COMMERSONII) IN AN ARTISANAL SETNET FISHERY IN LA ANGELINA BEACH AND RÍA GALLEGOS, SANTA CRUZ, ARGENTINA
}

\author{
Miguel A. Iñíguez ${ }^{1, *}$, Marta Hevia ${ }^{1}$, Cecilia Gasparrou ${ }^{1}$, Ana L. Tomsin ${ }^{1}$ and Eduardo R. Secchi ${ }^{2}$
}

\begin{abstract}
The Commerson's dolphin, Cephalorhynchus commersonii, is perhaps the cetacean species most impacted by fisheries in the coastal waters of southern South America, south of $41^{\circ}$ S. Between January 1999 and February 2000, 66 Commerson’s dolphins were found dead on the coasts of La Angelina and Ría Gallegos ${ }^{3}$, and at least 37 of the ones at La Angelina beach $\left(51^{\circ} 20^{\prime} \mathrm{S}, 069^{\circ} 02^{\prime} \mathrm{W}\right)$ were caught incidentally. These captures occurred in gill nets that were set in waters shallower than $15 \mathrm{~m}$ and mainly for Patagonian blenny (Eleginops maclovinus), silversides (Odonthestes nigricans) and parona leatherjack (Parona signata). The season for set net fishing, extending from the end of August to mid February, overlaps with the breeding season (NovemberFebruary) of Commerson's dolphins, which is also when this species moves inshore. The estimated catch per unit of effort (CPUE) for gillnets in the area of La Angelina was 0.229 dolphins $x(1,000 \mathrm{~m} \text { of net } \times \text { set })^{-1}$. By extrapolation, the estimated total by-catch during the 1999/2000 fishing season in the region of La Angelina and Ría Gallegos was 179 dolphins (SD = 18.8; CI = 141 - 212). Although no abundance estimation of Commerson's dolphins in this region is available, the estimated level of bycatch is concerning. Recommendations for action to mitigate and further document the impact of set gillnets are presented.

Resumen - La tonina overa, Cephalorhynchus commersonii, se distribuye en aguas costeras del sur de Sudamérica, al sur de los 41donde es quizás la especie de cetáceos que mayor impacto ha tenido Entre enero de 1999 y febrero de 2000, se encontraron 66 Toninas overas muertas en la costa de La Angelina y de la Ría Gallegos, y al menos 37 de ellas fueron capturadas

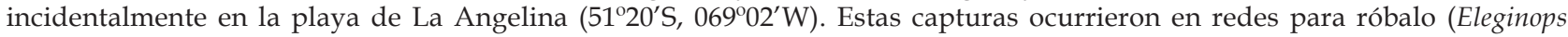
maclovinus), pejerrey (Odonthestes nigricans) y palometa pintada (Parona signata) principalmente. La temporada de pesca se extiende desde los últimos días de agosto hasta mediados de febrero, superponiéndose con la temporada reproductiva de la tonina overa (noviembre-febrero) cuando estos animales se desplazan hacia aguas costeras. Las capturas ocurrieron en aguas de menos de 15 metros de profundidad. La captura por unidad de esfuerzo (CPUE) estimada para las redes agalleras en el área de La Angelina fue de 0,229 delfines x $(1000 \mathrm{~m} \text { de red } x \text { lance })^{-1}$. Extrapolando, se estimó una captura incidental total de aproximadamente 179 delfines $(\mathrm{DS}=18,8 ; \mathrm{CI}=141$ - 212) durante la temporada de pesca 1999/2000 en la región de La Angelina y Ría Gallegos. Aunque no se dispone de una estimación de abundancia de toninas overas en esta región, la captura incidental estimada es preocupante. Se presentan recomendaciones para mitigar y documentar el impacto de las redes agalleras sobre la especie.
\end{abstract}

Keywords: commerson's dolphin, incidental catches, fisheries, catch per unit effort, Patagonia Argentina.

\section{Introduction}

The Commerson's dolphin, Cephalorhynchus commersonii, is distributed south of $41^{\circ} \mathrm{S}$ in the coastal waters of southern South America. It is also found in the waters of Islas Malvinas (Falkland Islands) and the Kerguelen islands (Goodall et al., 1988a; Leatherwood et al., 1988a; Iñíguez, 1991; Rice, 1998). In Argentine waters, there have been many reports of incidental capture of Commerson's dolphins in gillnets, trammel nets and mid-water trawls (Goodall and Cameron, 1980; Goodall et al., 1988b; Goodall et al., 1994; Crespo et al., 1994). In Santa Cruz Province, the incidental capture of 31 Commerson's dolphins in gillnets was recorded between 1983 and 1986 for Bahía Laura, Bahía San Julián, Bahía Media Luna, La Angelina and Cabo Buen Tiempo (Goodall et al., 19904). Despite its vulnerability to fishing activities and low reproductive potential (Iñíguez et al., $\left.2001^{5}\right)$, there is a lack of basic information (e.g. total bycatch, abundance, stock structure) to allow a proper assessment of the species' status under the IUCN Red List criteria. Therefore, it is currently listed as "Data Deficient" (Reeves, et al., 2003).

In the Ría Gallegos and up to La Angelina's beach (Fig.1), the gillnet season extends from the end of August to mid February, at which time the nets are used to target the Patagonian blenny (Eleginops maclovinus), silverside (Odonthestes nigricans), parona leatherjack (Parona signata) and southern king crab (Lithodes santolla). Set gillnets usually consist of rectangular, nylon monofilament or multifilament mesh panels that are fixed to the bottom of the littoral zone during low tide in areas that are shallower than approximately $12 \mathrm{~m}$ during high tide and set perpendicular to the shoreline (Fig.2). During high tide gillnets are completely submerged. Buoys at the top keep the net stretched in

\footnotetext{
${ }^{1}$ Fundación Cethus, J. de Garay 2861 Dto3, (B1636AGK), Olivos, Pcia. Buenos Aires, Argentina.

${ }^{2}$ Laboratório de Mamíferos Marinhos, Museu Oceanográfico "Prof. Eliézer C. Rios", Universidade do Rio Grande, Caixa Postal 379, Rio Grande, RS, 96200-970, Brazil. Current address: Marine Mammal Research Team, University of Otago, PO Box 56, Dunedin - New Zealand.

* Corresponding author: tovera@sanjulian.com.ar.

${ }^{3}$ Ría Gallegos and Río Gallegos refer to the river and the city, respectively.

${ }^{4}$ Goodall, R.N.P., Iñíguez, M.A. and Sutton, P. (1990) Capture of small cetaceans in gillnets off the province of Santa Cruz, Argentina. in Abstracts, IWC Symposium on Mortality of Cetacean in Passive Nets and Traps, October 1990, La Jolla, USA.

${ }_{5}^{5}$ Iñíguez, M.A., Tossenberger V.P. and Tomsin, A.L. (2001) Biology and Behaviour of Commerson's Dolphins (Cephalorhynchus commersonii) at Bahia San Julian,

Patagonia, Argentina. Page 105 in Abstracts, 14th Biennial Conference on the Biology of Marine Mammals. Vancouver, Canada.
} 
the water column. The catch is removed twice a day following the semi-diurnal tidal cycle and after a soak time of about 12 hours. The Subsecretariat of Fishing and Port Activities (Subsecretaria de Pesca y Actividades Portuarias - SPAP) has implemented a system with 20 fishing inspectors to control coastal fishing activities, especially relating to introduced trout that is a major tourist attraction.

In Santa Cruz Province, the provincial law No2582 declared the Commerson's dolphin to be a Provincial Natural Monument in July 2001 to protect the local resident populations. However, this Province does not have legislation regulating gillnet fisheries. Based on the incidental capture of Commerson's dolphins and sea birds in previous years, on 24 September 2001, SPAP issued Disposition $N^{\circ} 195$, which prohibited fishing with passive nets in Ría Gallegos, from the Güer Aike bridge to the Posterior beacon between 1 October and 7 December 2001 (Fig.1). It also banned the setting of passive nets with mesh greater than $70 \mathrm{~mm}$, from the Posterior beacon to Punta Loyola, for the same period. In January 1999, 12 dead Commerson's dolphins were reported in the Río Gallegos area. Nine of them had signs of entanglement in gillnets. This event led the local Secretariat of the Environment (Subsecretaría de Medio Ambiente de la Provincia de Santa Cruz - SMASC) to request a long-term study to assess the impact of the set gillnet fishery on C. commersonii in the area.

The objectives of this study are to: 1 ) estimate the dolphin catch per unit of effort (CPUE) for the La Angelina beach area during the season 1999/2000;2) estimate the total number of Commerson's dolphins captured from the Ría Gallegos and adjacent waters during the same season; 3) collect information on the set gillnet fishery; and 4) present recommendations to minimise by-catch in the future.

\section{Material and Methods}

\section{Study area}

La Angelina beach $\left(51^{\circ} 20^{\prime} \mathrm{S}, 069^{\circ} 02^{\prime} \mathrm{W}\right)$ is situated $150 \mathrm{~km}$ north of Río Gallegos. It has a pebbled beach approximately $5 \mathrm{~km}$ long (Fig.1). The mouth of the Ría Gallegos is $3.33 \mathrm{~km}$ wide. It extends from Punta Bustamante to Punta Loyola (51 $\left.36^{\circ} \mathrm{S}, 069^{\circ} 01^{\prime} \mathrm{W}\right)$. From Cabo Buen Tiempo (105m above sea level) to the south, the cliffs gradually diminish in elevation as they reach Punta Bustamante, at $32 \mathrm{~m}$, from which a pebble tongue, around $1400 \mathrm{~m}$ in length, forms the tip of the same name, and marks the northern limit of the Ría Gallegos. To the west of the Frontón beacon $\left(51^{\circ} 34^{\prime} \mathrm{S}, 069^{\circ} 03^{\prime} \mathrm{W}\right)$, there is

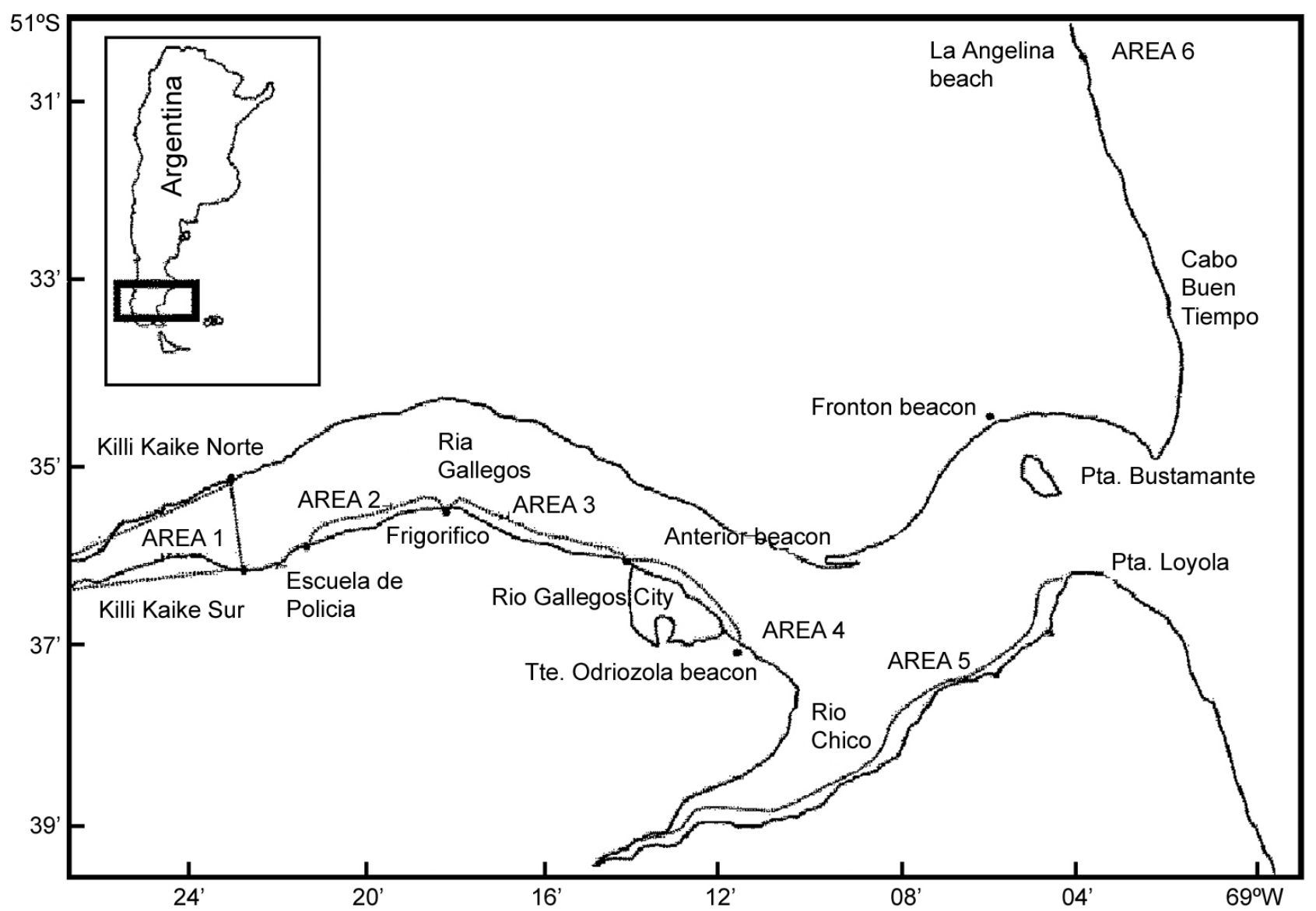

Figure 1. Fishing areas around Ria Gallegos estuary region, Santa Cruz province, southern Argentina. 


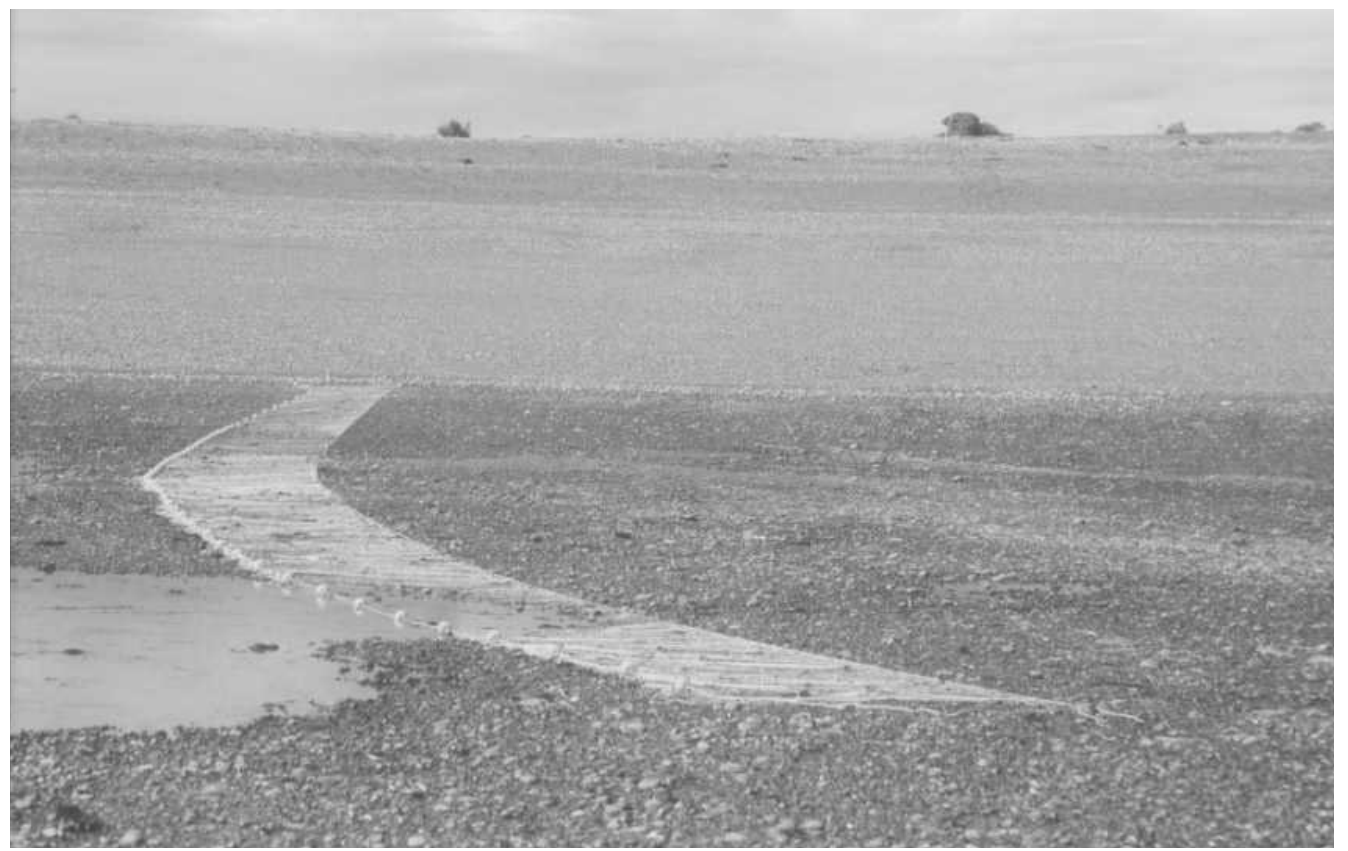

Figure 2. A typical coastal set gill net that is used in the waters of Ría Gallegos and La Angelina for Patagonian blenny and silversides and incidentally catches Commerson's dolphins. Because it is anchored to the ground, this type of net does not fish at low tide (above).

a low, pebbled coast, extending beyond the boundary of Río Gallegos' city. The sea coast to the south of Punta Loyola and the meridional shore of the river are flat and pebbled, covered with a layer of clay approximately $1 \mathrm{~m}$ thick. This geological characteristic continues for several kilometres inland (Ría Gallegos and La Angelina Armada Argentina, 1978). In the Ría Gallegos area, the maximum tidal amplitude is as high as $12 \mathrm{~m}$.

\section{Fishing areas}

Six coastal fishing areas between Ría Gallegos and La Angelina were defined by the SPAP: Area 1 (Inner Ría Gallegos), west of a straight line connecting Killi Kaike Norte lighthouse and Killi Kaike Sur (line 1); Area 2 (Escuela de Policía), police training school which is located north of Río Gallegos city; Area 3 (Frigorífico), from the end of Area 2 as far as the Anterior beacon (51 ${ }^{\circ} 36^{\prime} \mathrm{S}, 0^{\circ} 9^{\circ} 15^{\prime} \mathrm{W}$ ); Area 4 (Banco Cocozza) from the coast of Río Gallegos city to Tte. Odriozola beacon

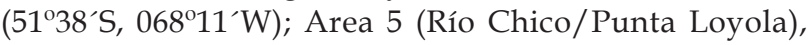
southern seacoast of Río Chico as far as Punta Loyola (51 $\left.36^{\circ} \mathrm{S}, 069^{\circ} 01^{\prime} \mathrm{W}\right)$; and Area 6 (La Angelina), the northernmost fishing location in the study area (Fig.1). Only four areas were considered for the analysis of the number of fishermen and nets (Escuela de Policía, Frigorífico, Río Chico/Punta Loyola and La Angelina) as no data were provided for Inner Río Gallegos and Banco Cocozza. Although in the Rio Gallegos and surrounding areas fishermen can use set gillnets, driftnets, and beach seining, only the former is used in La Angelina. Thus, all dolphins bearing evidence of net entanglement in La Angelina were confidently attributed to set gillnets and used for extrapolating the level of incidental mortality in the set gillnets used in the other areas.

\section{Catch and effort data}

During the $1999 / 2000$ season, specimens of Commerson's dolphins that were found dead in the La Angelina and Ría Gallegos regions were reported to the Fundación Cethus by local residents at the end of the 1999/2000 fishing season. All Commerson's dolphins were examined by researchers for evidence of entanglement, such as cuts or net marks. Whenever possible, specimens were collected for further examination in the laboratory. Morphometric data (following Norris, 1961) and tissues and teeth samples were collected from each carcass for further analyses. Each animal was classified as Group 1 (70-117cm), Group $2(117.1-127 \mathrm{~cm})$ or Group 3 (>127.1cm), following Goodall et al. (1988a). Males and females were considered adults when their total length exceeded 127$131 \mathrm{~cm}$ and $130 \mathrm{~cm}$, respectively (Goodall et al., 1988a). The condition of each specimen was classified into one of the five categories of Geraci and Lounsbury (1993): 1 - live animal; 2 - recently deceased; 3 - moderate decomposition; 4 - advanced decomposition and 5 mummified or skeletal.

The CPUE was calculated only for specimens captured in La Angelina during the 1999/2000 fishing season because reliable estimates of the number of animals caught and fishing effort were available only from this area. Even though, fishemen are allowed to use nets between 1.8 and $2.5 \mathrm{~m}$ high (see below), with very few exception, they always choose the largest. Although the 
information on net width is not available for all localities, it is assumed that the nets from La Angelina are a representative sample to all nets used in the region. Therefore, the CPUE was expressed as the number of dolphins captured in 1000 linear meters of gillnet per set (Commerson's dolphins $x\{1000 \mathrm{~m}$ net $\mathrm{x}$ set $\}^{-1}$ ) instead of the number of dolphins per area of net. Only those specimens belonging to decomposition categories from 2 to 4 and bearing evidence of entanglement were included in the analysis (individuals of category 5 were very likely to have been caught in the previous fishing season).

For this work, fishing days (= number of sets) are defined as the number of days a fisherman was licensed to fish in the season. This number varied between 82 and 150 license days based on the date each fisherman obtained the license. Assuming that Commerson's dolphins are equally vulnerable to bycatch in different areas (i.e., the by-catch rate estimated for La Angelina is the same for the other areas), we estimated the number of entangled dolphins in gillnets set in the areas of Escuela de Policía, Frigorífico, Río Chico/Punta Loyola and La Angelina. Data on the fishing effort for these areas were available from SPAP (Tables 1 and 2). Because we only had information on the total number of dolphins caught incidentally in the La Angelina area $(\mathrm{n}=37)$ and not the number of dolphins caught by each fisherman, we assumed that the number of dolphins caught by each fisherman was proportional to the fisherman's effort in that season.

The CPUE was estimated by dividing the number of dolphins captured by the total effort. Variation in the CPUE and in the total capture was calculated from bootstrapped random re-sampling of a set of the seven fishermen from La Angelina. The information associated with each fisherman included: 1) number of dolphins caught; 2) number of licensed fishing days in the season; 3) average amount of net that was set in a fishing day; and 4) total effort in the season (i.e., the product between 2 and 3 ) (see Table 1). The combination of effort and captures of each fisherman was fixed for each loop rather than randomly combining the effort of one fisherman with the capture of another for each loop. This constraint prevents a fisherman from fishing more days than his/her license allows in the bootstrap simulation.

Total by-catch for all areas was then calculated as the product of CPUE, the mean total effort and the number of fishermen $(n=33)$. This estimate is valid only if the assumption that the dolphins are equally vulnerable in all areas is satisfied. Given the data were not normally distributed we provide empirical confidence intervals based on the $2.5^{\text {th }}$ and $97.5^{\text {th }}$

Table 1. Fishing effort and by-catch in La Angelina beach (A); and estimated total by-catch for all fishing areas (B).

\begin{tabular}{|c|c|c|c|c|c|c|c|}
\hline \multicolumn{8}{|c|}{ A - FISHING EFFORT AND BY-CATCH IN LA ANGELINA } \\
\hline Fisherman & $\begin{array}{l}\text { Number of } \\
\text { Licensed } \\
\text { days }\end{array}$ & $\begin{array}{l}\text { Net size } \\
(\mathrm{m})\end{array}$ & $\begin{array}{l}\text { Number } \\
\text { of Nets }\end{array}$ & $\begin{array}{l}\text { Daily effort } \\
\text { (m of net) }\end{array}$ & $\begin{array}{l}\text { Total effort } \\
\text { (m of net) }\end{array}$ & $\begin{array}{c}\text { Number of } \\
\text { dolphins } \\
\text { caught }\end{array}$ & CPUE \\
\hline 1 & 150 & 50 & 4 & 200 & 30000 & 7 & - \\
\hline 2 & 146 & 50 & 3 & 150 & 21900 & 5 & - \\
\hline 3 & 114 & 50 & 4 & 200 & 22800 & 5 & - \\
\hline 4 & 150 & 50 & 4 & 200 & 30000 & 7 & - \\
\hline 5 & 115 & 50 & 5 & 250 & 28750 & 7 & - \\
\hline 6 & 82 & 50 & 4 & 200 & 16400 & 4 & - \\
\hline 7 & 114 & 50 & 2 & 100 & 11400 & 3 & - \\
\hline TOTAL & 871 & & 26 & 186 (mean) & 161757 & 37 & 0.229 \\
\hline \multicolumn{8}{|c|}{ B - ESTIMATED TOTAL BY-CATCH FOR EACH FISHING AREA BASED ON CPUE FROM LA ANGELINA } \\
\hline Fishing Area & $\begin{array}{c}\text { Number of } \\
\text { Licensed } \\
\text { days }\end{array}$ & $\begin{array}{l}\text { Net size } \\
(\mathrm{m})\end{array}$ & $\begin{array}{c}\text { Number of } \\
\text { fishermen and } \\
\text { (nets) }\end{array}$ & $\begin{array}{l}\text { Daily effort } \\
\text { (m of net) }\end{array}$ & $\begin{array}{l}\text { Total effort } \\
\text { (m of net) }\end{array}$ & CPUE & $\begin{array}{c}\text { Total } \\
\text { by-catch }\end{array}$ \\
\hline $\begin{array}{l}\text { Escuela de } \\
\text { Policia }\end{array}$ & 105 & 50 & $2(4)$ & 200 & 21000 & 0.229 & 5 \\
\hline Frigorifico & 137.5 & 50 & $11(47)$ & 2350 & 323125 & 0.229 & 74 \\
\hline $\begin{array}{l}\text { Rio Chico/P. } \\
\text { Loyola }\end{array}$ & 122.9 & 50 & $13(35)$ & 1750 & 215075 & 0.229 & 49 \\
\hline La Angelina & 124 & 50 & $7(26)$ & 1300 & 161200 & 0.229 & 37 \\
\hline
\end{tabular}


percentiles of the re-sampled distribution after 10,000 loops (Mainly, 1997).

\section{Results}

Description of the Fishery

The artisanal shore-based fishery (see below) is controlled by SPAP which, since 1999, has operated a licensing system and has collected information. These fishing permits must be renewed every year and are valid from the end of August to the middle of February. Table 2 summarizes the number of licensed fishermen operating in four of the six fishing areas in Ría Gallegos in the 1999/2000 season. Each fisherman is allowed to operate up to 12 nets, each with 30 to $50 \mathrm{~m}$ length and
1.8 to $2.5 \mathrm{~m}$ height. The permitted stretched mesh size varied from 120 to $140 \mathrm{~mm}$ for catching Patagonian blenny and $160 \mathrm{~mm}$ for parona leatherjack. The largest number of fishermen operated in the Río Chico/Punta Loyola area $(n=13)$, but the main fishing effort occurred in the Frigorífico area, with 47 nets. The average number of permitted nets per fisherman was: 2 for the Escuela de Policía area, 4.27 for the Frigorífico area, 2.69 for Río Chico/Punta Loyola, and 3.71 for La Angelina.

\section{By-catch of Commerson's dolphins}

Between January 1999 and February 2000, 66 Commerson's dolphins were found dead along the coasts of La Angelina and Ría Gallegos. Of these, 20 dolphins were omitted from the analysis because they

Table 2. Registered fishing effort per fishing operation area in the Rio Gallegos region (August 1999 - February 2000).

\begin{tabular}{lcccc}
\hline \hline AREA & $\begin{array}{c}\text { ESCUELA } \\
\text { DE POLICÍA }\end{array}$ & FRIGORÍFICO & $\begin{array}{c}\text { RÍO CHICO/ } \\
\text { P. LOYOLA }\end{array}$ & $\begin{array}{c}\text { LA } \\
\text { ANGELINA }\end{array}$ \\
\hline \hline Licensed fishermen & 2 & 11 & 13 & 7 \\
Number of gillnets & 4 & 47 & 35 & 26 \\
\hline
\end{tabular}

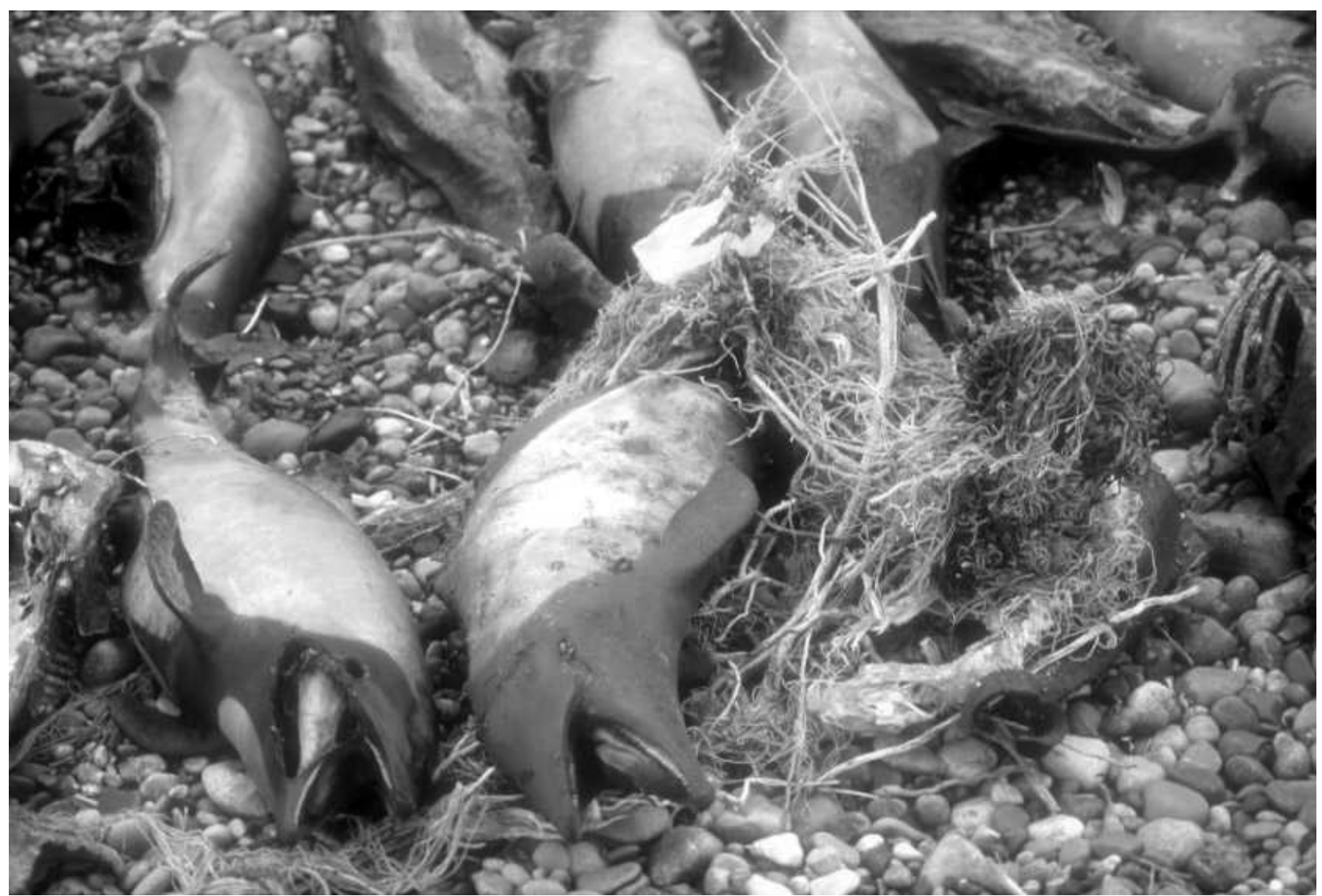

Figure 3. Eleven Commerson's dolphins found dead on La Angelina's beach. 
were in an advanced state of decomposition (Level 5), and may have died before the study period. Another nine animals that were presumed to have been caught between January and February 1999, before the fishing period analysed here (late August 1999 - mid February 2000), were also excluded from the analysis. Net marks were observed on 40 animals.

At least 37 Commerson's dolphins were caught incidentally by nets of the La Angelina area during the 1999/2000 season (Fig.3). The estimated CPUE of Commerson's dolphins in the area of La Angelina was 0.229 dolphins $\times(1,000 \mathrm{~m} \text { of net } x \text { set })^{-1}$ (Table $\left.1-A\right)$. Assuming that the dolphins are equally vulnerable in all areas (i.e., the CPUE is the same) the estimated total by-catch would be 165 animals during the season: 37 in La Angelina; 5 in La Policia; 74 in El Frigorifico and 49 in Rio Chico (Table 1-B). Bootstrapping produced an estimated mean by-catch of 179 dolphins for the four areas together $(\mathrm{SD}=18.8 ; \mathrm{CI}=141$ to 212$)$.

Out of 46 Commerson's dolphins examined, 8 (17.39\%) were at stage $3 ; 18(39.13 \%)$ were at stage 4 ; and $20(43.48 \%)$ at stage 5 of decomposition. Considering the 39 animals classified into length groups, 14 (35.9\%) were included in Group $1(\bar{x}=99.09 \mathrm{~cm}, \mathrm{SD}=12.72)$, of which 7 were males and 3 females; 8 (20.5\%) animals belonged to Group 2, ( $\bar{x}$ $=121.26 \mathrm{~cm}, \mathrm{SD}=2.73)(1$ male and 7 females $)$ and; 17 $(43.6 \%)$ dolphins were classified as Group $3(\bar{x}=137.6 \mathrm{~cm}$, $\mathrm{SD}=4.9)$ (8 males and 6 females).

\section{Discussion}

\section{Commerson's dolphin by-catch}

The problem of incidental mortality of Commerson's dolphins in fishing operations in Santa Cruz Province, including La Angelina, has been known for at least two decades (Goodall et al., 1990). However, no attempt to estimate the magnitude of by-catch has occurred thus far and the seriousness of the problem has only been suspected but not evaluated (e.g. Goodall et al., 1988b, 1990, 1994). The estimate of total by-catch presented here, though preliminary, is an attempt to show the magnitude of the problem. It indicates that the mortality is high but potentially biased. The total by-catch could be overestimated if: 1) the averaged amount of net and license days in other areas is lower than the average for La Angelina; 2) the catch rates in other areas were lower than La Angelina due to differences in the distribution patterns or densities of the dolphin; 3 ) naturally killed dolphins or dolphins killed by other fisheries or other human activities were assigned wrongly to by-catch in set gill nets. However, if dolphins exhibit the same distribution pattern in all areas and if fishing effort is similar throughout the region then total by-catch will more likely be underestimated because some fishermen are known to hide by-caught dolphins and, in such case, the number of dolphins by-caught in La Angelina would be under-represented. Also, net marks could have been missed on animals in an advanced state of decomposition (state 4) so the number of dolphins assigned as being caught in set gill nets would be fewer. The catch rate of La Angelina might be underestimated if fishermen did not fish all days they were licensed to fish. Furthermore, there were two fishing locations not included in the analyses as no data on fishing effort were available. We believe the currently available evidence strongly suggest that the by-catch is underestimated, though to an unknown extent. Underestimating by-catch of cetaceans by fishing activities is a common problem (e.g. Perrin et al., 1994; Secchi et al., 2002; Hall, 1999) and results especially when estimates are based on incomplete data but even when data come from onboard observer programs (e.g. Bravington and Bisack, 1996). Despite the potential biases, this first estimate shows that the amount of Commerson's dolphins caught annually in the study area is high. It is clear that systematic monitoring of the fishing activities is crucial to improve the accuracy of the estimates. Parallel studies on population discreteness and on abundance estimates at the population level are necessary for evaluating the impact of entanglement in set gillnets on the dolphin populations (see recommendations).

Although during the 2000/2001 fishing season, the mortality of Commerson's dolphins could not be monitored systematically, in only two months, between January and February 2001, about 30 dolphins that were caught incidentally in gillnets were reported to us by the Argentine Coast Guard and Nautical Club. Again, the number of dolphins caught is probably larger than that reported because some of the captured dolphins are cut open by fishermen in attempts to sink the carcasses and because some illegal nets are set by poachers who take advantage of the limited number of inspectors patrolling such a large area. The small number of fishing inspectors and the large distances between fishing areas may facilitate the increase of poaching activities and the dolphin bycatch. The reported level of by-catch in two months supports our suspicion that the total by-catch of Commerson's dolphins in the area is high and that prompt action to mitigate the problem is needed.

Almost $80 \%$ of the analysed Commerson's dolphins from La Angelina were allocated to length Group 1 and 3 (adults). The vast majority of studies dealing with by-catch of cetaceans in gillnets report that immature non-calves represent the higher percentage of entanglements (e.g. Slooten, 1991; Read and Hohn, 1995; Secchi et al., 2003). The high percentage of dolphins from these in Group 1 and 3 could be explained by the increase in number of adults and calves in coastal waters during November and December (Iñíguez et al., 2001). The high vulnerability of adult females to these set gillnets is further reason for concern because high mortality of this class constrains the potential rate of population growth and 
increases the likelihood of population decline (e.g. Slooten et al., 2000; Caswell, 2001).

In order to assess and mitigate the effect of the by-catch on the population of Commerson's dolphins in Ría Gallegos and La Angelina as well as in other areas along Santa Cruz Province, it is recommended to: 1) estimate the population size for Commerson's dolphins in a local basis; 2) improve information on artisanal fisheries using passive nets (e.g., CPUE, fishing techniques, number of registered/licensed fishermen and those fishing illegally, number of nets per fishing area); 3) undertake systematic surveys of cetacean by-catch levels in gillnets along Santa Cruz Province; 4) determine the age and reproductive status of all Commerson's dolphins captured as well as to determine population structure based on genetic and other analyses; 5) approve and promulgate the proposed Law $\mathrm{N}^{\circ} 157$ that regulates freshwater (river and lakes) and marine fishing (coastal and off shore) off Santa Cruz. This Law refers to the use of encircling gillnets and the ban of gillnets and other passive fishing gears; 6) work with artisanal fishermen in seeking alternative fishing techniques that replace passive nets and allow the fishermen to continue their livelihoods; 7) increase the number of fishing inspectors and to provide them with the necessary equipment to fishing control; 8) develop a cooperative agreement between Argentine Coast Guard and the SPAP to continue coastal fisheries control; and 9) undertake an environment awareness campaign at local level.

\section{Acknowledgements}

The authors wish to thank the following people and institutions for their support during the fieldwork: Almada R., Anglesio F., Beltrán A. and family, Bracalenti J.C., CeMA, Cendrón C. and family, Cumar H.D., de Tezanos Pinto G., Dubravcic, J.C., Escuela Guatemala from Río Gallegos, Failla M., Frizón H., Huertas G., Nieto H., Prefectura Naval Argentina from Río Gallegos and Islas Malvinas, Pref. Ppal. M.A. Casala, Pozzi C., Rodríguez T. and family, Rodríguez M., Subprefectura San Julián, Subsecretaría de Medio Ambiente - Santa Cruz, Subsecretaría de Pesca - Santa Cruz, Stuzembaun S. and family, Tommy Color, Torres E., Tournour G. and A. To the Subsecretaría de Pesca for provided unpublished information. J.Feghali, V.Tossenberger, K. van Waerebeek, V.Williams and A.Wood made useful comments on the manuscript. Finally, thanks are also given to S.Dans, J.Y.Wang, and one anonymous referee who provided good suggestions to improve the manuscript. This study was financially supported by the Subsecretaría de Medio Ambiente, the Subsecretaria de Pesca, and the Whale and Dolphin Conservation Society (UK). The Conselho Nacional para o Desenvolvimento Científico e Tecnológico - CNPq (Brazil) has granted graduate fellowships to E.R.Secchi (Grant no. 200889/98-2).

\section{References}

Bravington, M.V. and Bisack, K.D. (1996) Estimates of harbour porpoise bycatch in the Gulf of Maine sink gillnet fishery, 1990-1993. Report of the International Whaling Commission, 46: 567-574.

Caswell, H. (2001) Matrix Population Models: Construction, Analysis and Interpretation. $2^{\text {nd }}$ Edition. Sinauer Associates, Inc. Sunderland, USA.

Crespo, E.A., Corcuera, J.F. and López Cazorla, A. (1994) Interactions between Marine Mammals and Fisheries in some coastal fishing areas of Argentina. Report of the International Whaling Commission (Special Issue 15): 269-281.

Geraci, J.R. and Lounsbury, V.J. (1993) Marine mammals ashore. A field guide for strandings. Texas A\&M Sea Grant College Program Publication, Galveston.

Goodall, R.N.P. (1978) Report on small cetaceans stranded on Tierra del Fuego. Scientific Reports of the Whales Research Institute 30: 197-230.

Goodall, R.N.P. and Cameron, I.S. (1980). Exploitation of small cetaceans off southern South America. Report of the International Whaling Commission 30: 445-450.

Goodall, R.N.P., Galeazzi, A.R., Leatherwood, S., Miller, K.W., Cameron, I.S., Kastelein, R.K. and Sobral, A.P. (1988a) Studies of Commerson's dolphins, Cephalorhynchus commersonii, off Tierra del Fuego, 1976-1984, with a review of information on the species in the South Atlantic. Report of the International Whaling Commission (Special Issue 9): 3-70.

Goodall, R.N.P., Galeazzi, A.R. and Lichter, A.A. (1988b) Exploitation of small cetaceans off Argentina 1979-1986. Report of the International Whaling Commission 38: 407-10.

Goodall, R.N.P., Schiavini, A.C.M. and Fermani, C. (1994) Net fisheries and net mortality of small cetaceans off Tierra del Fuego, Argentina. Report of the International Whaling Commission (Special Issue 15): 295-304.

Hall, M.A. (1999) Estimating the ecological impacts of fisheries: what data are needed to estimate bycatches? Pages 175-184 in Nolan, C.P. (Ed.) Proceedings of the International Conference on Integrated Fisheries Monitoring. Sydney, Australia, 1-5 February 1999. Rome, FAO. 378pp.

Iñíguez, M.A. (1991) Tonina overa, Cephalorhynchus commersonii (Lacépede, 1804). Pages: 78-82 in Capozzo, H.L. and Junín, M. (Eds) Estado de conservación de los mamíferos marinos marinos del Atlántico Sudoccidental. Informes y estudios del Programa de Mares Regionales del PNUMA (UNEP) 138.

Leatherwood, S., Kastelein, R.A. and Miller, K.W. (1988). Observations of Commerson's dolphin and other cetaceans in Southern Chile, January-February 1984. Report of the International Whaling Commission (Special Issue 9): 71-83.

Mainly, B.F.J. (1997) Randomization, Bootstrap and Monte Carlo Methods in Biology. $2^{\text {nd }}$ Edition. Chapman \& Hall, London.

Norris, K.S. (1961) Standardized methods for measuring and recording data on smaller cetaceans. Journal of Mammalogy. 42: 471-476.

Read, A.J. and Hohn, A.A. (1995) Life in the fast lane: the life history of harbour porpoises from the Gulf of Maine. Marine Mammal Science, 11(4): 423-440.

Reeves, R.R., Smith, B.D., Crespo, E.A. and di Sciara, G.N. (Compilers) (2003) Dolphins, Whales and Porpoises: 2002-2010 Conservation Action Plan for the World's Cetaceans. IUCN/SSC Cetacean Specialist Group. IUCN. Gland, Switzerland and Cambridge.

Rice, D.W. (1998) Marine Mammals of the World, systematics and distribution. The Society for Marine Mammalogy. Special Publication Number 4: 231p. 
Secchi, E.R., Ott, P.H. and Danilewicz, D. (2002) Report of the Fourth Workshop for the Coordinated Research and Conservation of the Franciscana Dolphin (Pontoporia blainvillei) in the Western South Atlantic. The Latin American Journal of Aquatic Mammals 1 (Special Issue 1): 11-20.

Secchi, E.R., Ott, P.H. and Danilewicz, D. (2003) Effects of fishing by-catch and conservation status of the franciscana dolphin, Pontoporia blainvillei. In Gales, N., Hindell, M. and Kirkwood, R. (Eds) Marine Mammals and
Humans: Fisheries, Tourism and Management Issues. CSIRO Publishing. Collingwood.

Servicio de Hidrografía Naval - Armada Argentina (1978) Derrotero Argentino. $7^{\text {th }}$ Edition: 432-463.

Slooten, E. (1991) Age, growth, and reproduction in Hector's dolphins. Canadian Journal of Zoology, 69: 1689-1700.

Slooten, E., Fletcher, D. and Taylor, B. (2000) Accounting for uncertainty in risk assessment: case study of Hector's dolphin mortality due to gillnet entanglement. Conservation Biology. 14(5): 1264-1270. 